癌免疫療法の新展開 : 免疫チェック阻害剤の歴史

-Programmed death-1（PD-1）を中心に一

青木 友和

京都医療センター脳神経外科

\title{
New Development of Cancer Immunotherapy: History of Immunity Check Inhibitors Focusing on Programmed Death-1 (PD-1)
}

\author{
Tomokazu Aoki, M.D., Ph.D. \\ Department of Neurosurgry, Kyoto Medical Center
}

Immunotherapy for cancer began in the 1890s in the form of Coley's toxin, and in 1950 Burnett proposed the theory on the mechanism of immunological monitoring. In the early 1980s, Rosenberg et al., of the National Cancer Center of the USA (NCI) established lymphokine-activated killer (LAK)/cytotoxic T lymphocyte (CTL) therapy, and a Japanese neurosurgical group joined this field with the introduction of cytokine gene transfer therapy in the 1990s. Until this stage, cancer immunotherapy had generally been looked at skeptically. However, in 1996 Allison showed for the first time that antibody blockade of a T-cell inhibitory molecule (known as CTLA-4) can lead to enhanced antitumor immune response and tumor rejection. On the other hand, in 1992 in the laboratory of Professor Tasuku Honjo, Programmed cell death 1 (PD-1) was isolated and identified as a gene whose expression is strongly induced at the time of death of $\mathrm{T}$ lymphocytes ( $\mathrm{T}$ cells). It was proved to cause autoimmune disease in 1999 and was shown to act as an immunity checkpoint in 2000. Recently, a breakthrough was made in cancer immunotherapy via PD-1based immunity checkpoint inhibitors, leading to a new era in the field of cancer treatment. However, in the case of glioblastoma and the like, the effect of PD-1 antibody alone is insufficient, and the establishment of combination therapy with other drugs is anticipated.

(Received March 15, 2018 ; accepted April 17, 2018)

Key words : cancer immunotherapy, immune check point, programmed death-1 (PD-1)

Jpn J Neurosurg（Tokyo） $27: 712-722,2018$

\section{はじめに}

癌の免疫療法は, Coley toxin に始まり, LAK/CTL 療 法, サイトカイン遺伝子導入療法が続き, この段階まで は癌の免疫療法は, 治療法としては一般的には懐疑的な 目でみられていた。しかし， $\mathrm{PD}^{-1}$ を中心とした免疫 チェックポイント阻害剤によって癌免疫療法はブレイク
スルーをきたして, 癌治療体系に大きな変革を及ぼして いる (Fig. 1).

\section{Coley toxin}

癌の免疫療法に，最初に気づき報告したのは外科医の William B. Coley といわれている ${ }^{6)}$. Coleyは, 肉腫患者

連絡先：青木友和， ～６12-8555 京都市伏見区深草向畑町 1-1 京都医療センター脳神経外科

Address reprint requests to: Tomokazu Aoki, M.D., Ph.D., Department of Neurosurgery, Kyoto Medical Center, 1-1 Mukaihata-cho, Fukakusa, Fushimi-ku, Kyoto 612-8555, Japan 


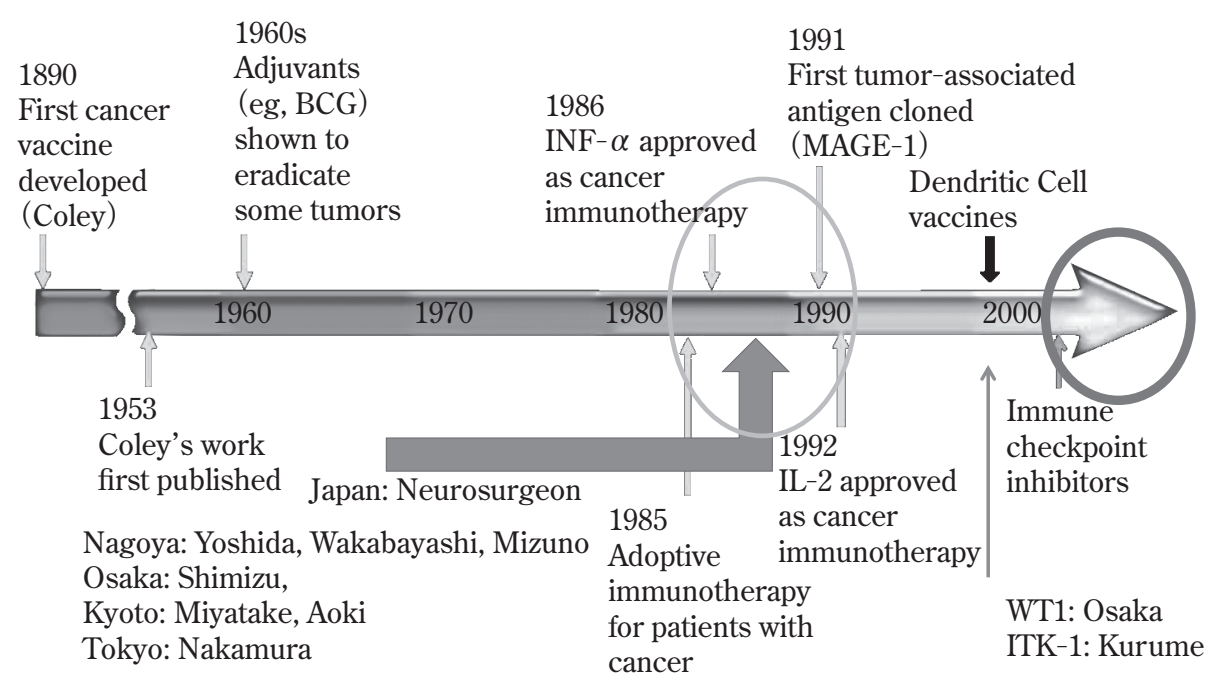

Fig. 1 Key events in the history of cancer immunotherapy

が，化膿レンサ球菌として知られる丹毒に感染し高熱を 出した後に腫瘍が消えたことを経験した。過去の文献を 調べてみると, コッホ, パスッールなどの先人も, 丹毒 感染に伴う腫瘍の退縮を記録していた。 Coley は, 1891 年に咽頭腫瘍の患者に, 初めて丹毒を意図的に感染させ る治療を行った。患者の症状は，著しく改善してその後 8 年余り生存した。彼は, がん治療に細菌が利用できる と考え, Coley 毒もしくは Coley ワクチンと呼ばれる死 菌の混合物を開発した。そして, 彼は手術不能の腫瘍患 者に対して, 化膿レンサ球菌を直接注射する治療を始め た。この治療はある程度の効果を示し転移腫瘍にも効果 を示した。発熱と本格的な感染を併発した患者ほど効果 は著しかった。試行錯誤の後, 彼は死んだ化膿レンサ球 菌とセアチア球菌の混合物を用いることにした ${ }^{6)} .19$ 世 紀終わりまでに, 欧州と北米で 42 人の医師がこのワク チンの成功例を報告した。この頃, 放射線治療も大きな 進歩があり，治療効果も安定し痛みもコントロールでき たため, 治療効果の不安定な免疫療法は, この後広く普 及しなかった。

Coley の研究記録は, 今日の臨床試験のデータと比較 するのは記録の不備が多く困難であった。しかし, 癌免 疫の治療の可能性を指摘した意味はきわめて大きいと思 われる。

日本では，丸山ワクチンが有名であるが，コンセプト は, Coleyワクチンと同じである. 1956年, 丸山千里は, ライ菌を保持しているハンセン病患者は, 癌の発生が低 いことを観察した。ライ菌と結核菌は, 同じ好酸性桿菌 であることから, 結核菌抽出物質の丸山口クチンが癌に 効果があるとの仮説を立てた ${ }^{21}$. JGOG（Japanese Gyne- cologic Oncology Group）“子宮䅡がんに対する（化学）放 射線療法. immunomodulator Z-100（丸山ワクチン）vs. プラセボ、第 3 相ランダム化比較試験”では，想定より 死亡率が低く, 統計学的有意差は認められなかったもの の局所進行子宮䅡がんに対し Z-100（丸山ワクチン）併 用群で良好な傾向がみられた ${ }^{37)}$.

\section{免疫学的監視機構}

1950 年代に入ると, Burnett らによって, 免疫学的監 視機構説が提唱された ${ }^{19)}$ 。これは, 生体内では, 悪性細 胞が常に産生されており免疫応答によって排除されてい るという説である。 T細胞が欠損した胸腺欠損ヌードマ ウスは, NK 細胞が残存しているためか, 癌の発症頻度 に有意差を認められなかった。しかし, 2001 年には, 免 疫応答の多様性に関与する免疫グロブリン遺伝子組み換 え遺伝子 (RAG 遺伝子) 欠損マウスでは, 癌の発症頻度 は上昇していた。癌の免疫監視機構仮説を支持するデー タであった ${ }^{34)}$.

\section{免疫細胞療法（LAK 療法，CTL 療法など）}

1980 年代初め, 米国国立がんセンター (NCI) の Rosenberg らは, 癌患者から大量のリンパ球を採取し, interleukin（IL）-2で数日間刺激し活性化リンパ球を誘導し て, IL-2 とともに点滴で戻す免疫細胞療法を施行した。 これが, LAK（リンフォカイン活性化キラー細胞：1ymphokine-activated killer cell）療法とよばれた。この療法 は，期待したほどの効果もなく, IL-2 の副作用も強く, 
IL-2 : Fearon et al. ${ }^{11)}$

IL-4 : Tepper et al. ${ }^{39)}$

IL-7 : Aoki et al. ${ }^{1)}$

IL-10: Richter et al. ${ }^{31)}$

GM-CSF: Dranoff, et al. ${ }^{10)}$

TNF- $\alpha$ : Blankenstein et al. ${ }^{2)}$

INF- $\boldsymbol{\beta}:$ Mizuno et al. ${ }^{22)}$

INF- $\boldsymbol{\gamma}:$ Watanabe et al. ${ }^{44)}$

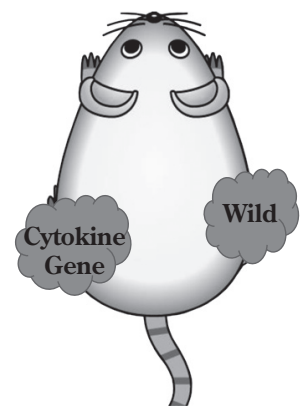

Around 1990

Fig. 2 Cytokine gene transfected tumor therapy

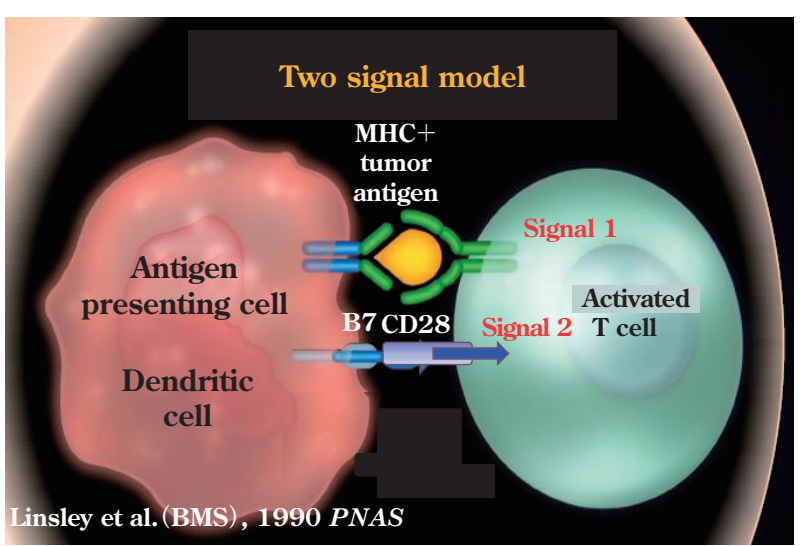

Fig. 3 Two signal model

患者からの大量のリンパ球採取は身体的負担も大きく, その後 LAK 療法は数年で衰退した ${ }^{32)}$.

この過程で，より高い効果を期待して, 腫瘍組織浸潤 活性化リンパ球療法（TIL）や細胞障害性活性化リンパ 球療法 (CTL) が考元出された。 TIL は, 腫瘍細胞に浸 潤しているリンパ球を手術で取り出して活性化する方法 であり, CTL 療法は, 培養中に手術で取り出した癌細胞 を混合させて刺激を繰り返し活性化する方法である。ど ちらも, 癌細胞で直接刺激することで癌細胞への特異性 を高める目的で行われた ${ }^{33)}$. しかし，CTL療法も期待ほ ど効果がなく発展しなかった。

膠芽腫に対しては，LAK/CTL療法ともに第 3 相試験 は報告されていない。第 $1 / 2$ 相試験の報告が中心とな る. 当時は生存期間よりも奏効率が沉用されており, 奏 効率 $20 \%$ 以上が抗癌剤の認可基準であった。残念なが ら, LAK/CTL 療法ともに奏効率は 2 割未満であり, か なりの手間とコストが必要であっためにそれ以上の進展
はなかった。そして, 第 3 相試験の報告もないため生存 期間の評価は困難であった ${ }^{42}$.

\section{サイトカイン遺伝子導入癌免疫療法 (Fig. 2)}

抗腫瘍免疫を賦活化するサイトカインの遺伝子を，患 者由来の免疫細胞や癌細胞に導入することによって，そ の細胞から患者の体内においてサイトカインの持続的産 生が得られるならば，局所癌免疫反応が高まり，腫瘍細 胞が排除されるという仮説に基づいて施行された。マウ 久実験では，有効性が報告されたが，ヒトに対してはあ まり発展しなかった ${ }^{320222)}$.

\section{2 シグナルモデル (two signal model) (Fig.3)}

$\mathrm{T}$ 細胞受容体（TCR）の $\alpha$ 鎖および $\beta$ 鎖が，腫瘍特異 抗原や抗原提示細胞 (APC) 表面の抗原 $(\mathrm{Ag})$ - 主要組織 適合抗原複合体 (MHC) に結合し，CD4 または CD8 が MHC と相互作用する。両作用によりアクセサリー分子 の CD 3 鎖を通して T 細胞が刺激される(第 1 シグナル). しかし, 第2（共活性化）シグナルがなければ， T細胞 はアネルギー状態または寛容状態のままである。 B7 と CD80 を介した第 2 のシグナルがあって, 初めて T 細胞 は活性化される ${ }^{20)}$.

\section{CTLA-4 (cytotoxic T lymphocyte antigen-4) (Fig. 4)}

1987 年に, CTLA-4 が Pierre Golstein らによって同定 された ${ }^{20)}$. 1990 年代初頭, Jim Allison と Jeff Bluestone は， CTLA-4 がT細胞応答を制限する阻害分子として働 くことを示した。1995 年 11 月, Tak Wah Mak おょび Arlene H. Sharpe の研究室は，マウスの遺伝子をノック アウトすることにより，CTLA-4の機能が T 細胞活性化 の負の調節因子として発見されたという発見を独自に発 表した ${ }^{15) 26) 40) 43) 45) ~}$

\section{CTLA-4 阻害抗体（Fig. 5)}

1996 年, JP. Allison は, T 細胞阻害分子（CTLA-4 とし て知られている）の抗体遮断が，抗腫瘍免疫応答および 腫瘍拒絶の増強をもたらし得ることを初めて示した ${ }^{15)}$. 抗腫瘍免疫応答を引き出し, 臨床的利益を引き出す方法 としての T細胞阻害経路を阻止するこの概念は, 「免疫 
チェックポイント療法」として標識された $\mathrm{T}$ 細胞阻害経

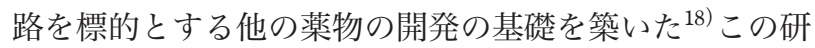
究は最終的に, 転移性黒色腫の治療のために米国食品医 薬品局 (FDA) によって 2011 年に承認されたイピリムマ ブ $\left(\right.$ YERVOY $\left.^{\circledR}\right)$ の臨床開発をもたらした

イピリムマブは，免疫系をダウンレギュレートする夕 ンパク質受容体である CTLA-4 を標的とすることによっ て免疫系を活性化するモノクローナル抗体である。

細胞傷害性 T リンパ球（CTL）は癌細胞を認識し破壞 することができる。しかし，阻害メカニズムがこの破壊 を妨げる ${ }^{4)}$.イピリムマブはこの阻害メカニズムを無効 にし，CTLを機能させる ${ }^{4) 38)}$.

イピリムマブは，皮膚癌の一種であるメラノーマの治 療のため，2011年にFDAによって承認された。非小細 胞肺癌 (NSCLC), 小細胞肺癌 (SCLC), 膀胱癌, およ び転移性ホルモン不応性前立腺癌の治療のための臨床試 験が行われた ${ }^{16) 28)}$.

癌を治療するために抗 CTLA4 抗体を使用するという 考え方は，カリフォルニア大学バークレー校の Cancer Research Laboratory のディレクターをしている間，JP. Allisonによって最初に開発された ${ }^{18)}$. 後でBristol-Myers Squibbによって取得された Medarexによって抗 CTLA-4 の臨床開発が開始された。2013 年現在, 費用は治療の過 程で 12 万ドルであった ${ }^{7)}$ ， イピリムマブの開発のため に, Allison は 2015 年にラスカー賞を受賞した。

\section{Cloning of Programmed Death-1 (PD-1) (Fig. 6)}

1992 年に京都大学 本庶 佑の研究室において, T リ ンパ球（T 細胞）の細胞死誘導時に発現が強くなる遺伝 子として PD-1（programmed cell death-1）が単離・同定 された ${ }^{13)}$ ，石田らは，幼弱 $\mathrm{T}$ 細胞が，自己を認識した場 合，自ら賢く死の運命を選択するが，その際に急上昇す る遺伝子を発見できれば，自己-非自己の識別の秘密を 解き明かすことができると考えた。最終的に 4 個の独立 した cDNAに辿り着き，それらはすべて同一の遺伝子 PD-1であった。

\section{PD-1 遺伝子ノックアウトマウス（Fig. 7)}

PD-1 分子の機能は，発見されてから数年にわたり不

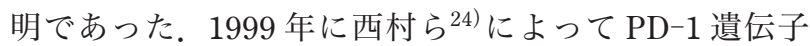
ノックアウトマウスが自己免疫疾患を起こすことが証明 され，PD-1 は，2000 年に免疫チェックポイントである

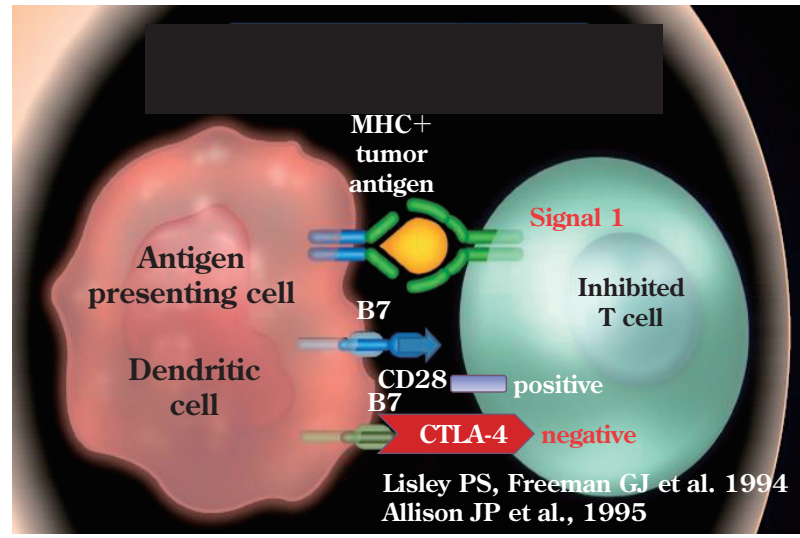

Fig. 4 CTLA-4: a negative competitive regulator with CD28 for B7

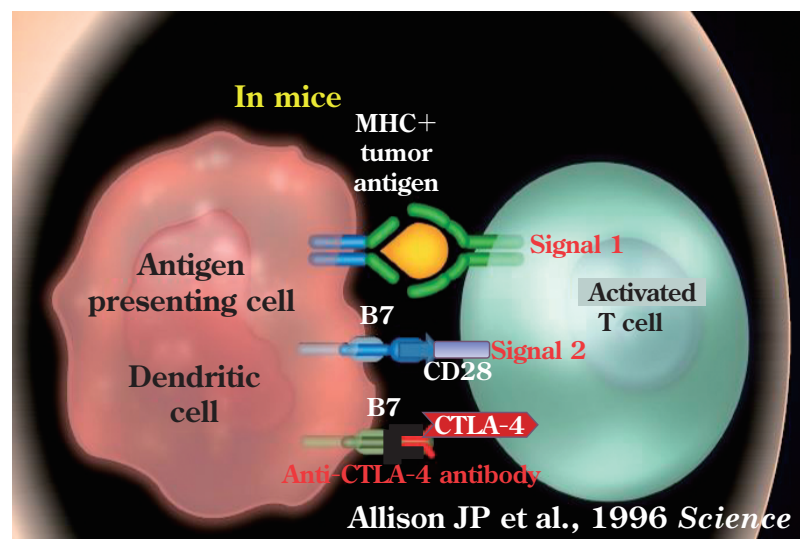

Fig. 5 CTLA-4 blockage

ことが最初に示された ${ }^{13)}$. 興味深いことに PD-1 遺伝子 ノックアウトマウスは，なかなか症状を示さないため, 当時の西村らは，かなり落胆しくじけそうになった。こ のマウスは, 自己免疫発症まで半年〜 1 年かかった ${ }^{23) 24)}$. この発症までの時間が遅いということは，癌治療におい て，非常に重要な意味をもつた。この症状の現れ方が緩 徐で弱いため，PD-1 抗体治療は副作用の少ない癌治療 につながっていく. CTLA-4 遺伝子ノックアウトマウス は，激しい自己免疫を短期間で発症し短期間で死に至 る ${ }^{20)}$ ．そ机は，非常にわかりやすく研究材料には適して いるが，臨床の癌治療には副作用の強さとして問題と なっている。

\section{B7/CD28 superfamily (Fig. 8 )}

CD28 ファミリー分子は CD28 や ICOS (inducible 
Honjo Labo. (around 1990)

\section{Cloning Project of apotosis genes}

Lymphoid system

PD-1 (Programmed Death-1)

Ishida et al., EMBO J, 1992

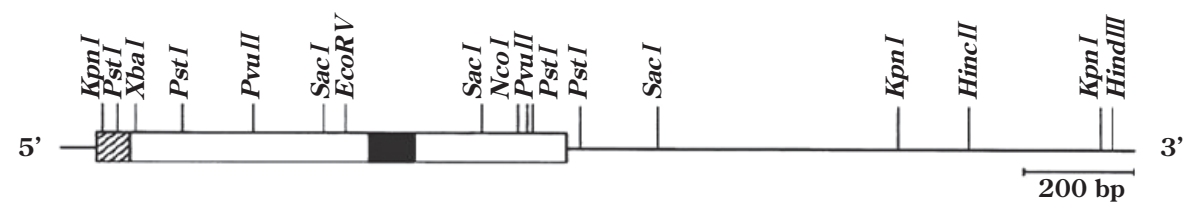

\section{Neuronal system Bip/Grp78 Aoki et al., J Biochem, 1997 \\ TAFII31 Aoki et al., BBRC, 1997}

Fig. 6 Cloning of Programmed Death-1 (PD-1)

PD-1 is a molecule responsible for autoimmune tolerance

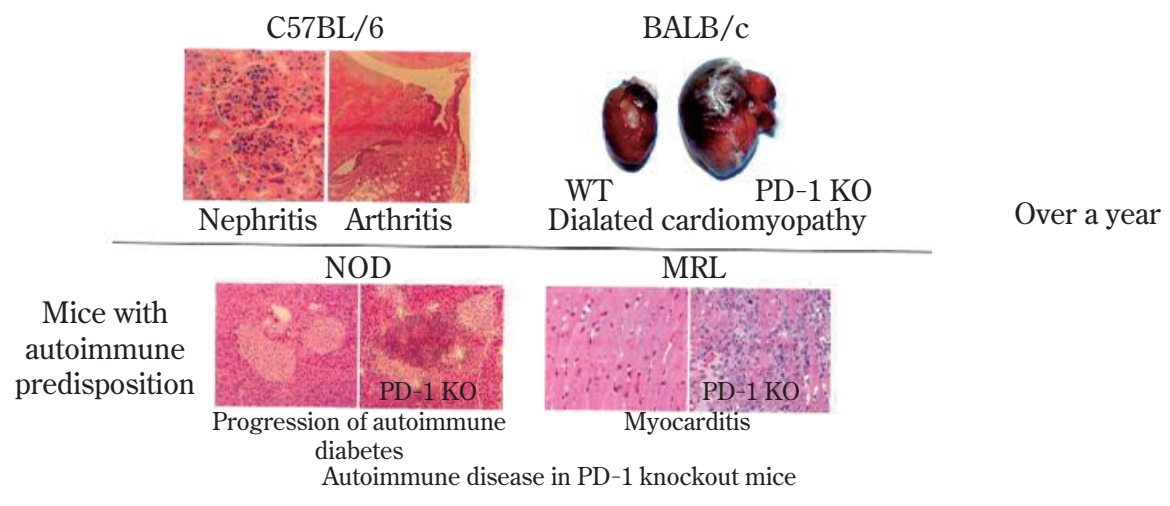

Nishimura et al., Immunity 1999, Science 2001

Fig. 7 PD-1 knockout mice

CTLA -4 knockout mice die at an age of 2-3 wk

Science 1995

costimulatory molecule）のように T 細胞上に発現して活 性化シグナルを伝達するものと, CTLA -4 や PD-1のよ うに抑制性シグナルを伝達するものに分けられる ${ }^{8) 36)}$. PD-1 は CTLA-4 と比べて活性化後比較的遅い時期に T 細胞上に発現する．PD-1の生理的なリガンドとしては PD-L1 および PD-L2 が同定され，いずれも B7 ファミ リーに属する。

免疫チェックポイント阻害剂の CTLA-4 抗体 (2011 年 承認）および $\mathrm{PD}^{-1}$ 抗体（2014 年承認）は $\mathrm{T}$ 細胞活性化 を抑制するシグナルを遮断することで，癌に対する T 細 胞免疫応答を高めることから，癌抗原に非特異的な分子 標的薬でありながら, 癌特異的な免疫応答を増強するこ
とができる。さらに, ハーバード大学の Gordon Freeman 博士らとの共同研究によって, PD-1に対するリガンド として 2 つの分子, PD-L1 (B7-H1) および PD-L2（B7DC) が相次いで同定された ${ }^{53} 36$. 限局的に発現する $\mathrm{PD}-$ 1 とは対照的に, PD-L1 はさまざまな細胞, 組織で広く 発現する。抗原提示細胞に加えて, 活性化した T 細胞や $\mathrm{B}$ 細胞などほとんどの免疫担当細胞に発現する。また， さまざまな臓器の実質細胞や血管内皮細胞などの非実質 細胞でも発現がみられ，ウイルス感染などでその発現レ ベルは上昇する。さらに，血液系腫瘍，皮膚癌，肺癌， 卵巣癌，乳癌などさまざまな種類の癌で発現が報告され ている。一方, PD-L2 の発現は限局的で, 抗原提示細胞 


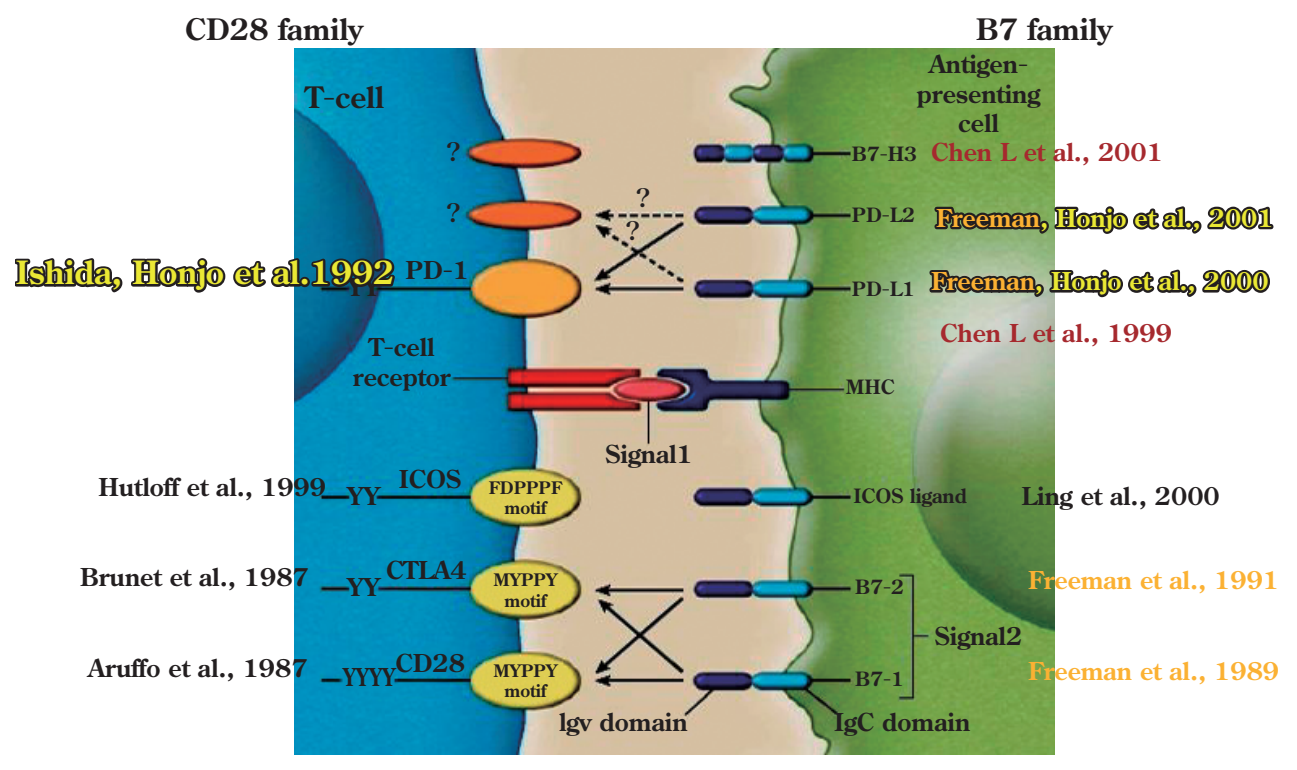

Fig. 8 B7/CD28 superfamily

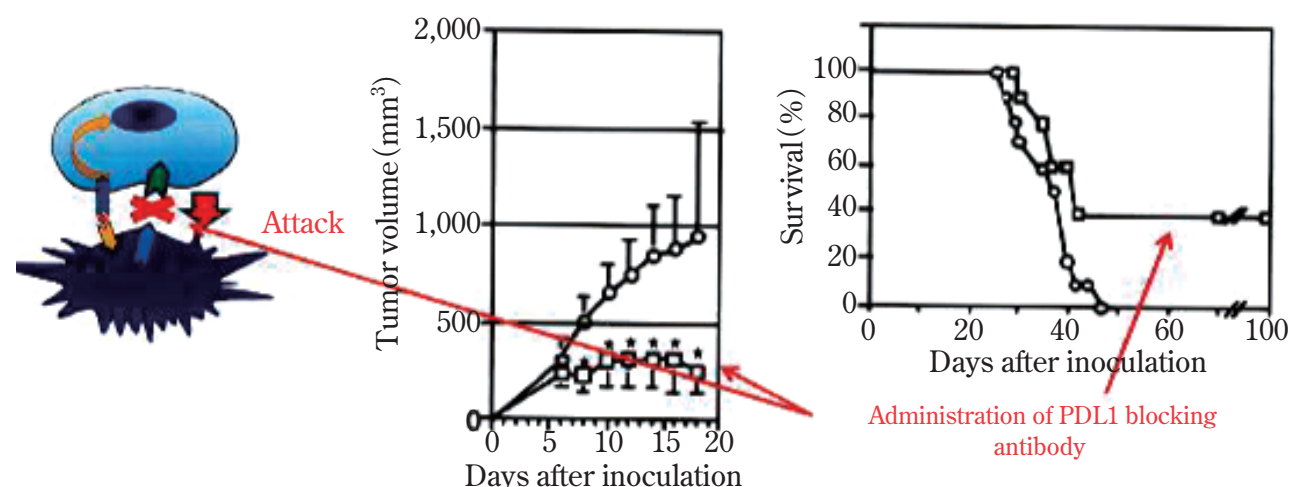

Days after inoculation

Lieping Chen Group., Nature Med 2002

Honjo Labo.

Iwai et al, PNAS, 2002

Fig. 9 Binding inhibition of PD-1 with PDL1 suppress myeloma in mice

上に発現がみられる。

\section{PD-1/PD-L1 結合阻害による腫瘍抑制 (Fig. 9)}

PD-1 遺伝子ノックアウトマウスで自己免疫疾患が発 症することが示され，それをもとに癌や感染症の治療に も応用できるのではないかという仮説が導かれた。しか し，癌治療モデルの確立はそう簡単ではなかった。理由 のひとつには，ヒトに比べるとマウスでは PD-1 阻害に よる抗腫瘍効果が弱く, PD-1 抗体阻害剂に感受性のあ る腫瘍は限定されることが考えられる。岩井らは，PDL1 をマウス腫瘍に強制発現させて，PD-1 阻害の感性を
付与し，苦労の末， 2002 年の世界で初めて PD-1 阻害治 療のモデルを確立した ${ }^{14)}$.

\section{PD-1 阻害機構（Fig. 10）}

免疫応答で炎症が起こると樹状細胞をはじめリンパ組 織および末梢組織のさまざまな細胞が PD-L1 を発現す る。一方，抗原刺激や炎症刺激により $\mathrm{T}$ 細胞上に $\mathrm{PD}-1$ の発現が誘導される. PD-L1 は PD-1 と結合すると T細 胞の機能を抑制し，免疫寛容を誘導して，過剩な免疫応 答を抑え組織傷害から生体を守る。癌細胞は PD-L1を発 現することによって，T細胞の活性化を抑制し，宿主の 


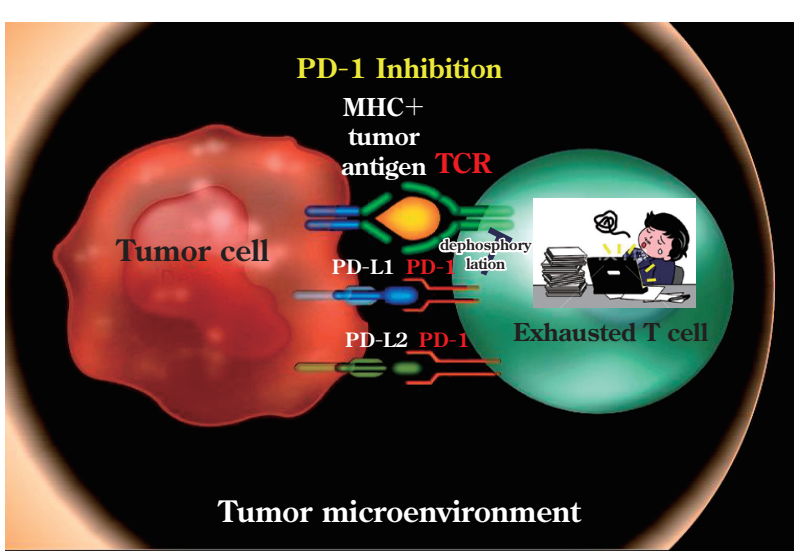

Fig. 10 PD-1 Inhibition

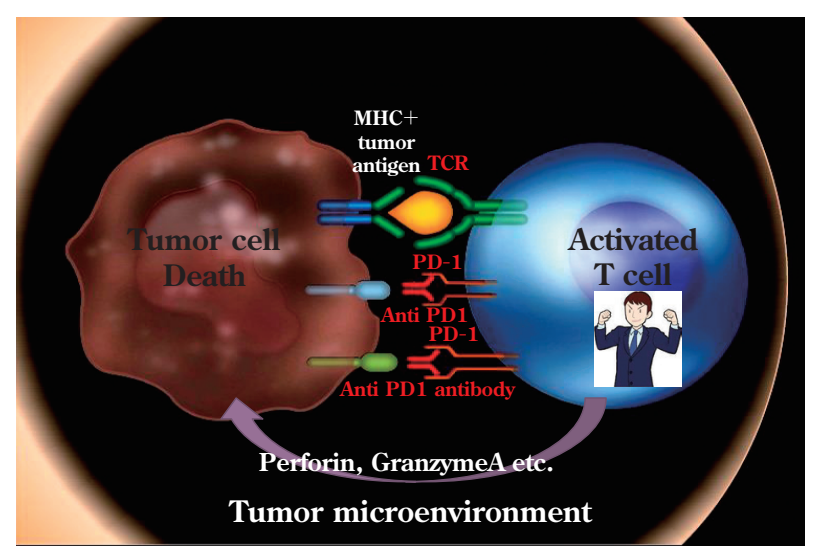

Fig. 10 PD-1 Inhibition (2)

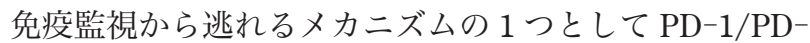
L1 シグナルを利用する ${ }^{8) 25)}$. 抗 PD-1/PD-L1 抗体により この抑制性シグナルを遮断すると T 細胞が活性化し, 癌 に対する免疫応答が増強する。

\section{PD-1 抗体：臨床開発の流れ（Fig. 11）}

マウスモデルで，PD-1 シグナルを阻害すると腫瘍が 抑制されるという結果を受けて, 本庶らは小野薬品に臨 床試験の実施をもちかけた。しかし，2000 年代は腫瘍免 疫は眉唾物，手を出すと企業が潰れるといわれて，製薬 企業は開発に参入しなかった。それゆえ，小野薬品と賛 同して一緒に PD-1 抗体治療の臨床化を進める製薬企業 は国内外にいなかった。 PD-1 阻害による抗体治療の特 許が公開されて, 米国のベンチャー企業, Medarex 社が 共同開発を申し出てきた。そして, 2005 年に Medarex 社 と小野薬品が，世界で初めて PD-1 ヒト抗体の作成に成
功した。 2009 年には, Bristol-Myers Squibb 社が, Medarex 社を買収合併した。米国資本の力技であった。

\section{Breakthrough of year 2013 (Fig. 12)}

2006 年には，ヒトへの応用が開始され，治療抵抗性の 非小細胞癌，大腸癌，メラノーマ，腎癌，前立腺癌に第 1 相臨床試験が米国で行われた。約 $20 \sim 30 \%$ の奏効率を 示し, 1 年以上の治療効果を認める症例も多かった ${ }^{810)}$. この報告を皮切りに，世界中であらゆる癌種で臨床試験 が激烈に始まった。現在，肺癌，メラノーマ，腎癌，胃 癌，ホジキンリンパ腫 (cHL), 頭䅡部癌に対して保険適 応が取得された。

2012 年に公表された有望な臨床試験の結果は, 業界ア ナリストと主流メディアの間で興奮を引き起こした。

PD-1 はその時点で生物学的標的として積極的に追求さ れていたが, pembrolizumab (Keytruda), Roche（子会社 の Genentech 経由), atezolizumab, GlaxoSmithKline とメ リーランド州のバイオテクノロジー企業 Amplimmune, Teva はイスラエルのバイオテクノロジー企業 CureTech との競争で協力している3541)

小野薬品は 2014 年 7 月, 日本で切除不能黒色腫に対す る PD-1 阻害剤の承認を受けた。これは世界で初めて承 認された PD-1 阻害剤である。

Merck は, 2014 年 9 月に PD-1 阻害剤, pembrolizumab (Keytruda) の FDA 承認を受けた。

Nivolumab は，2014 年 12 月にメラノーマ治療薬とし て FDA 承認を取得した。2015 年 4 月，欧州医薬品庁 (European Medicines Agency)の人的使用のための医薬品 委員会は，nivolumabの単剤療法としての転移性メラ ノーマの承認を推奨した。同年 3 月, 米国 FDA は扁平上 皮細胞癌の治療薬として承認した。 6 月 19 日，欧州委員 会は，欧州連合全体で有効な販売許可を与えた。11月 に，FDA は，nivolumabを，腎細胞癌の第 2 選択薬とし て承認した。 2016 年 5 月, FDA は，自家造血幹細胞移植 (自己 HSCT) および移植後の brentuximab vedotin の後に 再発または進行した古典的なホジキンリンパ腫患者の治 療のために nivolumab を承認した。

Bristol-Myers Squibb 社は，膠芽腫（GBM）の初回再 発患者を対象に nivolumab の有効性と安全性を評価した 第 3 相無作為化臨床試験である CheckMate-143 試験が, bevacizumab 単剂療法と比較して，主要評価項目である 全生存期間の改善を達成しなかったことを発表した。こ れらのデータは，スイス，チューリッヒで開催された世 界脳腫瘍学会連合（World Federation of Neuro-Oncology 


\begin{tabular}{l|l}
\hline 2002 & PD-1:Patent acquisition by Honjo and ONO Co.(2002/July 3) \\
\hline 2005 & $\begin{array}{l}\text { Full humanized ant-PD-1 antibody } \\
\text { Joint application by ONO and Medarex company } \\
\text { Application of IND (investigational new drug) was approved by US FDA(2006/August 1) }\end{array}$ \\
\hline 2009 & Medarex was purchased by Bristol-Myers Squibb \\
\hline
\end{tabular}

Fig. 11 PD-1 antibody: Stream of clinical development

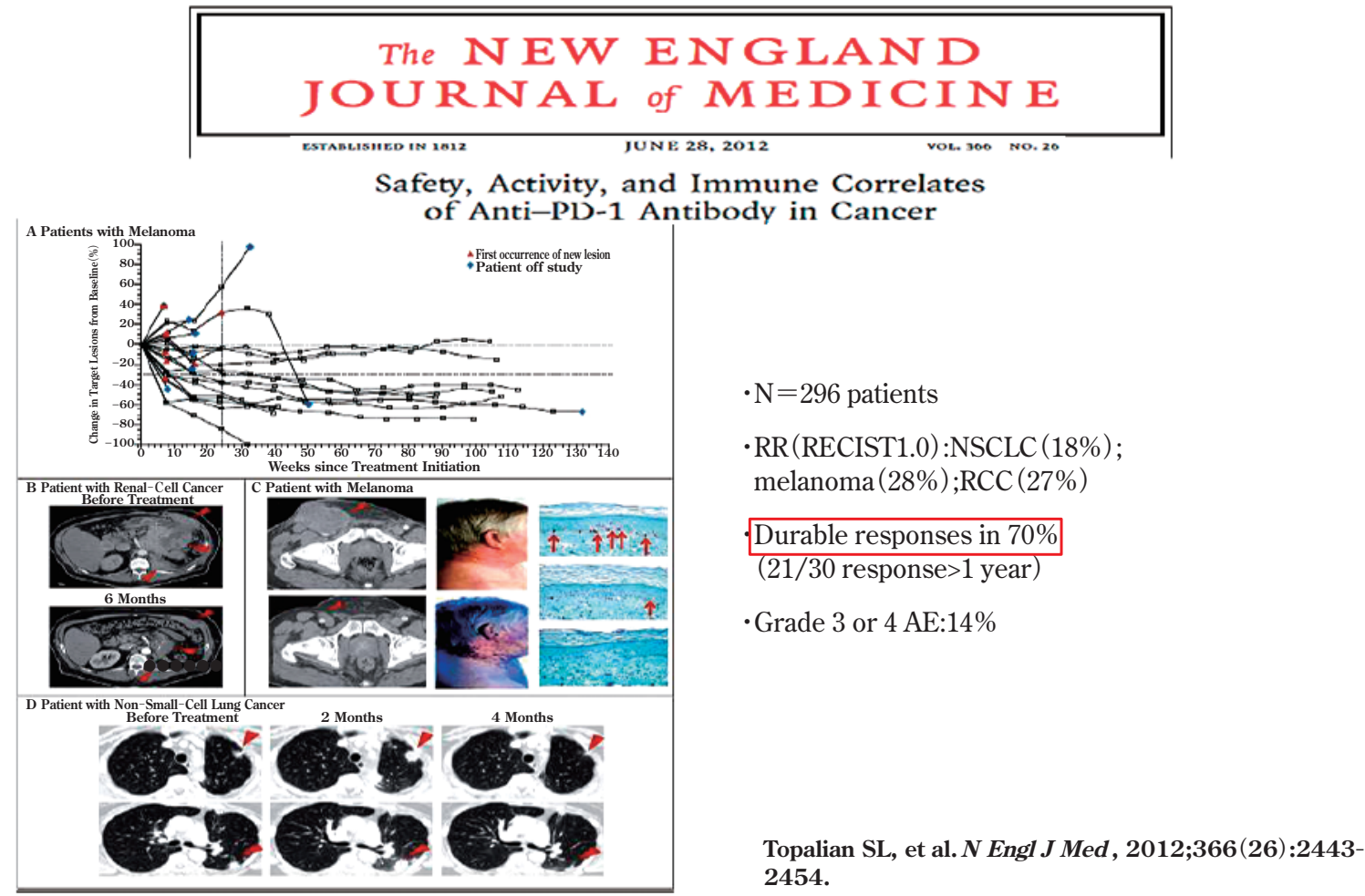

Fig. 12 PD-1 inhibition antibody : Memorial clinical report/Breakthrugh of year 2013

Societies : WFNOS) 総会において, 2017 年 5 月 7 日に発 表された ${ }^{29)}$. 初発膠芽腫の nivolumab 療法の第 3 相試験 は現在進行中である。

PD-1 抗体治療は, 癌免疫療法のブレイクスルーと なった。英国の雑誌 New Scientist は, PD-1の発見は, 細菌におけるペニシリンに似ていると表現している。癌
免疫治療（免疫チェックポイント）の治療は始まったば かりである。脳腫瘍などは, PD-1 抗体単剤では効果が 不十分であり, 他剤との併用療法が今後期待される。

\section{COI の開示}

著者は日本脳神経外科学会への COI 自己申告を完了してい 
ます。また，本論文に関して開示すべき COI はありません.

謝 辞

1988～2005 年まで本庶 佑研究室に在籍して，PD-1 遺伝 子の単離から初期の機能解析までリアルタイムにみる機会を 得られたことに感謝します。

\section{文 献}

1) Aoki T, Tashiro K, Miyatake S, Kinashi T, Nakano T, Oda $Y$, Kikuchi H, Honjo T: Expression of murine interleukin 7 in a murine glioma cell line results in reduced tumorigenicity in vivo. Proc Natl Acad Sci US A $89: 3850-3854,1992$.

2) Blankenstein T, Qin ZH, Uberla K, Müller W, Rosen H, Volk HD, Diamantstein T: Tumor suppression after tumor celltargeted tumor necrosis factor alpha gene transfer. J Exp Med 173: 1047-1052, 1991.

3) Brunet JF, Denizot F, Luciani MF, Roux-Dosseto M, Suzan M, Mattei MG, Golstein P : A new member of the immunoglobulin superfamily-CTLA-4. Nature 328:267-270, 1987.

4) Cavallo J : Immunotherapy Research of James P. Allison, $\mathrm{PhD}$, Has Led to a Paradigm Shift in the Treatment of Cancer (15 September, 2014). The ASCO Post. http://www. ascopost.com/issues/september-15-2014/immunother apy-research-of-james- ${ }^{-}{ }^{-}$-allison-phd-has-led-to-a-para digm-shift-in-the-treatment-of-cancer/(Retrieved 4 August 2016)

5) Chapoval AI, Ni J, Lau JS, Wilcox RA, Flies DB, Liu D, Dong H, Sica GL, Zhu G, Tamada K, Chen L : B7-H3 : a costimulatory molecule for $\mathrm{T}$ cell activation and IFN-gamma production. Nat Immunol $2: 269-274,2001$.

6) Coley WB: Treatment of malignant tumors by repeated inoculation of erysipelas : with a report of 10 cases. Am J Med Sci 105: 487-564, 1893.

7) Couzin-Frankel J : Breakthrough of the Year : cancer immunotherapy. Science 342: 1432-1433, 2013.

8) Dong H, Zhu G, Tamada K, Chen L: B7-H1, a third member of the B7 family, co-stimulates T-cell proliferation and interleukin-10 secretion. Nat Med 5: 1365-1369, 1999.

9) Dong H, Strome SE, Salomao DR, Tamura H, Hirano F, Flies DB, Roche PC, Lu J, Zhu G, Tamada K, Lennon VA, Celis E, Chen L : Tumor-associated B7-H1 promotes T-cell apoptosis: a potential mechanism of immune evasion. Nat Med 8: 793-800, 2002.

10) Dranoff G, Jaffee E, Lazenby A, Golumbek P, Levitsky H, Brose K, Jackson V, Hamada H, Pardoll D, Mulligan RC : Vaccination with irradiated tumor cells engineered to secrete murine granulocyte-macrophage colony-stimulating factor stimulates potent, specific, and long-lasting antitumor immunity Proc Natl Acad Sci U S A $\quad \mathbf{9 0}$ : 3539-3543, 1993.

11) Fearon ER, Pardoll DM, Itaya T, Golumbek P, Levitsky HI, Simons JW, Karasuyama H, Vogelstein B, Frost P : Interleukin-2 production by tumor cells bypasses $\mathrm{T}$ helper function in the generation of an antitumor response. Cell $\quad 60: 397-$ 403, 1990.

12) Freeman GJ, Long AJ, Iwai $Y$, Bourque $K$, Chernova T, Nishimura H, Fitz LJ, Malenkovich N, Okazaki T, Byrne MC, Horton HF, Fouser L, Carter L, Ling V, Bowman MR, Carreno BM, Collins M, Wood CR, Honjo T : Engagement of the PD-1 immunoinhibitory receptor by a novel B7 family member leads to negative regulation of lymphocyte activation. J Exp Med 192: 1027-1034, 2000.

13) Ishida $Y$, Agata $Y$, Shibahara K, Honjo T : Induced expression of $\mathrm{PD}^{-1}$, a novel member of the immunoglobulin gene superfamily, upon programmed cell death. EMBO J $\mathbf{1 1}$ : 3887-3895, 1992.

14) Iwai $Y$, Ishida $M$, Tanaka $Y$, Okazaki T, Honjo T, Minato $N$ : Involvement of $\mathrm{PD}-\mathrm{L} 1$ on tumor cells in the escape from host immune system and tumor immunotherapy by PD-L1 blockade. Proc Natl Acad Sci U S A 99: 12293-12297, 2002.

15) Krummel MF, Allison JP : CD28 and CTLA-4 have opposing effects on the response of T cells to stimulation. J Exp Med 182: 459-465, 1995.

16) Lacroix M : Targeted Therapies in Cancer. New York, Nova Sciences Publishers, 2014.

17) Latchman $Y$, Wood CR, Chernova T, Chaudhary D, Borde M, Chernova I, Iwai Y, Long AJ, Brown JA, Nunes R, Greenfield EA, Bourque K, Boussiotis VA, Carter LL, Carreno BM, Malenkovich N, Nishimura H, Okazaki T, Honjo T, Sharpe $\mathrm{AH}$, Freeman GJ : PD-L2 is a second ligand for $\mathrm{PD}^{-1}$ and inhibits T cell activation. Nat Immunol 2:261-268, 2001.

18) Leach DR, Krummel MF, Allison JP : Enhancement of antitumor immunity by CTLA-4 blockade. Science 271: 1734-1736, 1996.

19) Lesterhuis WJ, Haanen JB, Punt CJ : Cancer immunotherapy-revisited. Nat Rev Drug Discov $\quad 10: 591-600,2011$.

20) Linsley PS, Clark EA, Ledbetter JA : T-cell antigen CD28 mediates adhesion with $\mathrm{B}$ cells by interacting with activation antigen B7/BB-1. Proc Natl Acad Sci USA 87 : 5031-5035, 1990.

21）丸山千里：結核菌体抽出物質および腫瘤組織抽出物質に よる悪性腫瘍の治療について (予報) 1. 結核菌体抽出物 質による悪性腫瘍の治療について。 日皮会誌 76:399404, 1966.

22) Mizuno M, Yoshida J, Sugita K, Inoue I, Seo H, Hayashi Y, Koshizaka T, Yagi K: Growth inhibition of glioma cells transfected with the human $\beta$-interferon gene by liposomes coupled with a monoclonal antibody. Cancer Res $\quad \mathbf{5 0}: 7826^{-}$ $7829,1990$.

23) Nishimura H, Nose M, Hiai H, Minato N, Honjo T : Development of lupus-like autoimmune diseases by disruption of the PD-1 gene encoding an ITIM motif-carrying immunoreceptor. Immunity $\quad$ 11: 141-151, 1999.

24) Nishimura H, Okazaki T, Tanaka Y, Nakatani K, Hara M, Matsumori A, Sasayama S, Mizoguchi A, Hiai H, Minato N, Honjo T: Autoimmune dilated cardiomyopathy in PD-1 receptor-deficient mice. Science 291:319-322, 2001.

25) Okazaki T, Chikuma S, Iwai $Y$, Fagarasan S, Honjo T : A rheostat for immune responses : the unique properties of $\mathrm{PD}^{-1}$ and their advantages for clinical application. Nat Immunol 14: 1212-1218, 2013.

26) Pardoll, DM : Immunology beats cancer : a blueprint for successful translation. Nature Immunol $13: 1129-1132,2012$.

27) Pollack A : Drug Helps Defense System Fight Cancer. New York Times, 2012. https://www.nytimes.com/2012/06/02/ business/drug-helps-immune-system-fight-cancer.html (Retrieved May 30, 2015)

28) Pollack A: New Class of Drugs Shows More Promise in Treating Cancer (May 29, 2015). New York Times. https:// www.nytimes.com/2015/05/30/business/new-class- ${ }^{-}$of $^{-}$ 
drugs-shows-more-promise-in-treating-cancer.html (Retrieved May 30, 2015)

29) Reardon DA, Omuro A, Brandes AA, Rieger J, Wick A, Sepulveda J, Phuphanich S, de Souza P, Ahluwalia MS, Lim M, Vlahovic G, Sampson J : OS 10.3 Randomized Phase 3 Study evaluating the efficacy and safety of nivolumab vs bevacizumab in patients with recurrent glioblastoma : CheckMate 143. Neuro Oncol 19 (suppl 3) : iii21, 2017.

30) Ribas A: Tumor immunotherapy directed at PD-1. $N$ Engl J Med 366:2517-2519, 2012.

31) Richter G, Krüger-Krasagakes S, Hein G, Hüls C, Schmitt E, Diamantstein T, Blankenstein T : Interleukin 10 transfected into Chinese hamster ovary cells prevents tumor growth and macrophage infiltration. Cancer Res $\quad 53: 4134^{-}$ 4137, 1993.

32) Rosenberg SA, Lotze MT, Muul LM, Leitman S, Chang AE, Ettinghausen SE, Matory YL, Skibber JM, Shiloni E, Vetto JT, Seipp CA, Simpson C, Reichert CM : Observations on the systemic administration of autologous lymophokineactivated killer cells and recombinant interleukin-2 to patients with metastatic cancer. N Engl J Med $313: 1485^{-}$ 1492, 1985.

33) Rosenberg SA, Packard BS, Aebersold PM, Solomon D, Topalian SL, Toy ST, Simon P, Lotze MT, Yang JC, Seipp CA, Simpson C, Carter C, Bock S, Schwartzentruber D, Wei JP, White DE : Use of tumor-infiltrating lymphocytes and interleukin-2 in the immunotherapy of patients with metastatic melanoma. N Engl J Med 319: 1676-1680, 1998.

34) Shankaran V, Ikeda H, Bruce AT, White JM, Swanson PE, Old LJ, Schreiber RD : IFNgamma and lymphocytes prevent primary tumour development and shape tumour immunogenicity. Nature $\quad$ 410: 1107-1111, 2001.

35) Sharma P, Allison JP: The future of immune checkpoint therapy. Science $348: 56^{-61,2015 .}$

36) Sharpe AH, Freeman GJ : The B7-CD28 superfamily. Nat Rev Immunol 2: 116-126, 2002.

37) Sugiyama T, Fujiwara K, Ohashi Y, Yokota H, Hatae M, Ohno T, Nagai Y, Mitsuhashi N, Ochiai K, Noda K : Phase III placebo $^{-}$controlled double-blind randomized trial of radiotherapy for stage II B-IVA cervical cancer with or without immunomodulator Z-100 : a JGOG study. Ann Oncol 25 : 1011-1017, 2014.

38) Syn NL, Teng MWL, Mok TSK, Soo RA: De-novo and acquired resistance to immune checkpoint targeting. Lancet Oncol 18: e731-e741, 2017.

39) Tepper RI, Pattengale PK, Leder P : Murine interleukin-4 displays potent anti-tumor activity in vivo. Cell $\mathbf{5 7}: 503^{-}$ 512, 1989.

40) Tivol EA, Borriello F, Schweitzer AN, Lynch WP, Bluestone JA, Sharpe AH : Loss of CTLA-4 leads to massive lymphoproliferation and fatal multiorgan tissue destruction, revealing a critical negative regulatory role of CTLA-4. Immunity 3: 541-547, 1995.

41) Topalian SL, Hodi FS, Brahmer JR, Gettinger SN, Smith DC, McDermott DF, Powderly JD, Carvajal RD, Sosman JA, Atkins MB, Leming PD, Spigel DR, Antonia SJ, Horn L, Drake CG, Pardoll DM, Chen L, Sharfman WH, Anders RA, Taube JM, McMiller TL, Xu H, Korman AJ, Jure-Kunkel M, Agrawal S, McDonald D, Kollia GD, Gupta A, Wigginton JM, Sznol M : Safety, activity, and immune correlates of antiPD-1 antibody in cancer. $N$ Engl J Med 366 : 2443-2454, 2012.

42) Vauleon E, Avril T, Collet B, Mosser J, Quillien V : Overview of cellular immunotherapy for patients with glioblastoma. Clin Dev Immunol 2010 : pii : 689171, 2010.

43) Walunas TL, Lenschow DJ, Bakker CY, Linsley PS, Freeman GJ, Green JM, Thompson CB, Bluestone JA : CTLA-4 can function as a negative regulator of T cell activation. Immunity 1:405-413, 1994.

44) Watanabe Y, Kuribayashi K, Miyatake S, Nishihara K, Nakayama E, Taniyama T, Sakata T : Exogenous expression of mouse interferon gamma cDNA in mouse neuroblastoma C1300 cells results in reduced tumorigenicity by augmented anti-tumor immunity. Proc Natl Acad Sci US A $\quad \mathbf{8 6}$ : 94569460, 1989.

45) Waterhouse P, Penninger JM, Timms E, Wakeham A, Shahinian A, Lee KP, Thompson CB, Griesser H, Mak TW : Lymphoproliferative disorders with early lethality in mice deficient in Ctla-4. Science 270: 985-988, 1995. 
癌免疫療法の新展開 : 免疫チェック阻害剤の歴史

一Programmed death-1（PD-1）を中心に一

青木 友和

癌の免疫療法は, 1890 年代の Coley toxin に始まり, 1950 年に入ると, Burnett らによって, 免疫 学的監視機構説が提唱された. 1980 年代初め, 米国国立がんセンター (NCI) のローゼンバーグら は, LAK/CTL 療法を提唱し, 日本の脳神経外科グループもサイトカイン遺伝子導入療法で世界をリー ドした. しかし,この段階までは癌の免疫療法は, 一般的には懐疑的な目でみられていた. 1996 年, JP. Allison は, T細胞阻害分子 (CTLA-4 として知られている) の抗体遮断が, 抗腫瘍免疫応答および 腫掦拒絶の増強をもたらし得ることを初めて示した. 1992 年に京都大学 本庶 佑の研究室におい て, Tリンパ球（T 細胞）の細胞死誘導時に発現が強くなる遺伝子として PD-1 (programmed cell death 1)が単離・同定された. 1999 年に自己免疫疾患を起こすことが証明され, 2000 年に免疫チェッ クポイントであることが示された. そして, PD-1を中心とした免疫チェックポイント阻害剤によっ て癌免疫療法はブレイクスルーをきたして, 癌治療体系に大きな変革を及ぼしている. しかし, 膠芽 腫などでは, PD-1 抗体単剤では効果が不十分であり, 他剤との併用療法が今後期待されている. 